\title{
ANALISIS MUATAN KURIKULUM PENDIDIKAN KARAKTER DALAM KTSP DITINJAU DARI PEMBANGUNAN KARAKTER BANGSA
}

\author{
Yudi Hartono*
}

\begin{abstract}
Abstrak
Bangsa Indonesia saat ini sedang dihadapkan pada berbagai tantangan yang cukup berat. Salah satunya adalah persoalan karakter bangsa. Pendidikan yang berorientasi pada pembangunan karakter bangsa merupakan salah satu upaya strategis di tengah krisis identitas dan peradaban bangsa. Penelitian ini mengkaji muatan pendidikan karakter dalam KTSP dan relevansinya dengan upaya pembangunan karakter bangsa.

Penelitian dilakukan dengan studi pustaka. Data diperoleh dari sumber primer dan sekunder, yaitu dokumen KTSP dan bahan-bahan pustaka berkualifikasi tinggi terkait dengan kurikulum, pendidikan karakter, dan pembangunan bangsa serta bahan-bahan pustaka yang memberikan tambahan penjelasan atas sumber primer. Bahan-bahan yang terkumpul diolah, diidentifikasi, diklasifikasi, dianalisis dan dideskripsikan berdasarkan rumusan masalah yang pada akhirnya dijadikan bahan pengambilan kesimpulan dan saran.

Hasil penelitian menunjukkan bahwa KTSP 2006 mengandung 95 nilai karakter. Nilai-nilai tersebut telah mencakup tiga ranah (kognitif, afektif, dan psikomotorik) yang cukup seimbang sehingga tinggal bagaimana implementasi kurikulum tersebut di lapangan agar dapat mendukung pembangunan karakter bangsa yang diharapkan.
\end{abstract}

Kata kunci: KTSP, pendidikan karakter, pembangunan karakter bangsa

\section{Pendahuluan}

Bangsa Indonesia saat ini sedang dihadapkan pada berbagai tantangan yang cukup berat. Salah satunya adalah persoalan karakter bangsa. Berbagai peristiwa yang terekam media menyiratkan pertanya-an tentang karakter bangsa. Semula bangsa Indonesia yang dicirikan antara lain: ramahtamah, sopan santun, tolong meno- long, tenggang rasa, dan fleksibel, kini mulai bergeser. Penelitian Setiawati Darmojuwono dari Universitas Indonesia (2007) menunjukkan bahwa berbagai ledakan bom dan kerusuhan di berbagai daerah telah mengubah stereotipe tentang Indonesia di mata internasional. Stereotipe tentang Indonesia kini lebih bersifat negatif, seperti teroris, fundamentalis, koruptif, dan birokratis.

* Yudi Hartono adalah Dosen Program Studi Pendidikan Sejarah IKIP PGRI Madiun 21|Agastya Vol. 02 No. 02 . Juli 2012 
Para pendiri bangsa telah gejala krisis identitas. Norma-norma berhasil membangun bangsa (nation building), namun untuk membangun karakter bangsa masih memerlukan waktu yang panjang. Upaya membangun karakter bangsa mengalami pasang surut sejalan dengan pergulatan bangsa dalam menentukan arah perjuangan dan juga arah pembangunan.

Pada era pasca kemerdekaan, sebagai negara baru Indonesia diwarnai oleh pergulatan politik, terutama menyangkut persoalan ideologi negara yang akan menentukan wujud dan jatidiri bangsa di masa depan. Mekanisme melalai Konstituante mengalami jalan buntu sehingga kemudian ditempuh jalan Dekrit Presiden 1959 untuk kembali ke UUD 1945 dan ideologi Pancasila. Sejak saat itu, semangat untuk membangun kultur dan karakter berbasis Pancasila semakin menguat, namun dalam perjalanannya pembangunan yang terlampau berorientasi pada materi telah menumbuhkan kultur yang tidak sejalan dengan kultur yang ingin dikembangkan. Keberhasilan pembangunan ekonomi yang kurang diimbangi dengan pembangunan karakter bangsa telah mengakibatkan goncangan dan krisis budaya, yang kemudian berakibat pada lemahnya ketahanan budaya bangsa. Lemahnya ketahanan budaya tersebut tercermin antara lain dari lemahnya kemampuan dalam menyikapi dinamika perubahan sebagai akibat dari tuntutan zaman yang diwarnai oleh derasnya arus budaya global.

Lemahnya ketahanan budaya juga ditunjukkan oleh terjadinya lama Semakin melemah, sementara Norma baru belum terkonsolidasi dengan baik sehingga terjadi sikap ambivalensi dan disorientasi tata nilai. Disorientasi tata nilai yang terjadi bersamaan dengan tumbuhnya semangat kebebasan mengakibatkan pandangan permisif atau serba boleh. Hal tersebut berkembang secara berlebihan sehingga memicu konflik di berbagai daerah yang dapat menjadi indikasi semakin melemahnya karakter bangsa.

Azra (2002:5) menyatakan bahwa belum terbentuknya karakter dan kepribadian bangsa saat ini juga berhubungan dengan kegagalan Sistem pendidikan sebagaimana dinyatakannya berikut ini. "Secara garis besar, pencapaian pendidikan nasional masih jauh dari harapan, apalagi untuk bersaing secara kompetitif dengan perkembangan pendidikan pada tingkat global. Bahkan dan ini yang terpenting dalam konteks pembahasan sekarang. Pendidikan nasional bukan hanya belum Berhasil meningkatkan kecerdasan dan keterampilan anak didik, melainkan gagal dalam membentuk karakter dan kepribadian bangsa. (nation and charakter building)."

Krisis karakter bangsa dipersepsikan terkait juga dengan fenomena kurangnya harmoni dalam keluarga. Banyak keluarga mengalami disorientasi bukan hanya karena krisis ekonomi, melainkan juga karena terpaan globalisasi nilai-nilai dan norma gaya hidup hedonistikmaterialistik; yaitu gaya hidup yang mengutamakan kenikmatan bendawi. Gaya hidup ini diyakini tidak sesuai dengan nilai-nilai dan norma-norma 
agama dan sosial budaya masyarakat Indonesia. Tayangan dalam telenovela dan sinetron pada berbagai saluran televisi Indonesia banyak membawa muatan gaya hidup yang jauh dari kearifan lokal masyarakat.

Menurut Komaruddin Hidayat (2006:54) pendidikan yang berorientasi pada pembangunan karakter bangsa merupakan salah satu upaya strategis di tengah krisis identitas dan peradaban bangsa. Pendidikan ini menjadikan peserta didik sebagai subjek melalui cara-cara yang demokratis, partisipatif, kritis, dan menantang bagi aktualisasi diri mereka.

Pendidikan karakter berupaya mengenalkan, mensosialisasikan, membiasakan nilai kebaikan kepada seseorang sehingga menjadi bagian dari perilaku yang terinternalisasi atau mendarah daging. Berbeda dengan pendidikan moral, pendidikan karakter memiliki esensi lebih tinggi karena bukan sekedar mengajarkan mana yang benar dan mana yang salah, tetapi lebih dari itu mengajarkan karakter menanamkan kebiasaan tentang hal yang baik sehingga peserta didik menjadi paham (domain kognitif) tentang mana yang baik dan salah, mampu merasakan (domain afektif) nilai yang baik dan mampu melakukannya (domain psikomotor).

Pembangunan karakter dan jati diri bangsa merupakan cita-cita luhur yang harus diwujudkan melalui penyelenggaraan pendidikan yang terarah dan berkelanjutan. Bangsa Indonesia tidak pernah berhenti dalam menyelenggarakan program pendidikan dalam keadaan bagaimanapun. Pengembangan kurikulum pendidikan terus dilakukan agar lebih relevan dengan tantangan zaman.
Pasal 36 ayat (1) dan (2) UndangUndang Nomor 20 Tahun 2003 tentang Sistem Pendidikan Nasional menegaskan bahwa pengembangan kurikulum dilakukan dengan mengacu pada Standar Nasional Pendidikan. Kurikulum pada semua jenjang dan jenis pendidikan dikembangkan dengan prinsip diversifikasi sesuai dengan satuan pendidikan, potensi daerah, dan peserta didik. Kurikulum Tingkat Satuan Pendidikan (KTSP) yang berlaku saat ini merupakan hasil upaya pengembangan kurikulum yang diharapkan mampu memberi perubahan yang berarti terhadap hasil pendidikan dalam menghadapi tantangan, termasuk tantangan karakter bangsa.

Namun hingga saat ini kondisi bangsa diwarnai oleh berkembangnya perilaku yang sebelumnya tidak banyak muncul, antara lain: meningkatnya kekerasan di kalangan masyarakat; penggunaan bahasa dan katakata yang memburuk, pengaruh peergroup yang kuat dalam tindak kekerasan; meningkatnya perilaku merusak diri seperti penggunaan narkoba, alkohol, dan seks bebas; semakin kaburnya pedoman moral baik dan buruk; menurunnya etos kerja; semakin rendahnya rasa hormat kepada orang tua dan guru; rendahnya rasa tanggung jawab individu dan warga negara; membudayanya ketidakjujuran; dan adanya rasa saling curiga dan kebencian di antara sesama warga negara. Hal ini menarik untuk dikaji terkait dengan muatan pendidikan karakter dalam KTSP dan relevansinya dengan upaya pembangunan 
karakter bangsa yang diamanatkan oleh UUD 1945 dan UU Sistem Pendidikan Nasional.

Berdasarkan uraian di atas, maka rumusan masalah dalam penelitian ini sebagai berikut.

a. Bagaimanakah muatan pendidikan karakter dalam KTSP?

b. Bagaimanakah relevansi muatan pendidikan karakter dalam KTSP ditinjau dari upaya pembangunan karakter bangsa sesuai dengan tantangan zaman?

\section{Tujuan dan Manfaat Penelitian}

Berdasarkan rumusan masalah di atas, maka tujuan penelitian ini sebagai berikut.

a. Menganalisis dan menemukan muatan pendidikan karakter dalam KTSP.

b. Menganalisis dan menemukan relevansi muatan pendidikan karakter dalam KTSP ditinjau dari upaya pembangunan karakter bangsa sesuai dengan tantangan zaman.

Penelitian ini penting dilakukan sebagai bahan masukan bagi Kementrian Pendidikan Nasional dan para pengembang kurikulum dalam merancang dan mengembangkan muatan kurikulum pembangunan karakter bangsa yang mampu menjawab tantangan zaman.

\section{Tinjauan Pustaka}

\section{Pendidikan Karakter}

Karakter merupakan kumpulan tata nilai yang menuju pada suatu sistem, yang melandasi pemikiran, sikap, dan perilaku yang ditampilkan. Karakter sama dengan kepribadian. Kepribadian dianggap sebagai ciri, atau karakteristik, atau gaya, atau sifat khas dari diri seseorang yang bersumber dari bentukan-bentukan yang diterima dari lingkungan, misalnya lingkungan keluarga pada masa kecil dan juga bawaan seseorang sejak lahir (Qomari Anwar, 2010:2).

Karakter menunjukkan bagaiMana seseorang bertingkah laku. Apabila seseorang berperilaku tidak jujur, kejam, atau rakus, tentulah Orang tersebut memanifestasikan perilaku buruk. Sebaliknya, apabila seseorang berperilaku jujur, suka menolong, tentulah orang tersebut memanifestasikan karakter mulia. Seseorang baru bisa disebut orang yang berkarakter apabila tingkah lakunya sesuai kaidah moral. Orang yang berkarakter adalah orang yang mempunyai kualitas moral tertentu Yang positif. Dengan demikian, membangun karakter secara implisit mengandung arti membangun sifat atau pola perilaku yang didasari atau berkaitan dengan dimensi moral yang positif atau baik, bukan yang negatif atau buruk.

Peterson dan Seligman mengaitkan secara langsung antara karakter yang kuat dengan kebajikan. Karakter yang kuat dipandang sebagai unsur-unsur psikologis yang membangun kebajikan. Salah satu Kriteria utamanya adalah bahwa karakter tersebut berkontribusi besar Dalam mewujudkan sepenuhnya potensi dan cita-cita seseorang dalam membangun kehidupan yang baik, yang bermanfaat bagi dirinya, orang 
lain, dan bangsanya (Qomari Anwar, 2010:2).

Dari pendapat di atas dapat dipahami bahwa karakter berkaitan dengan kekuatan moral, berkonotasi positif, bukan netral. Orang berkarakter adalah orang yang mempunyai kualitas moral (tertentu) positif. Dengan demikian, pendidikan membangun karakter, secara implisit mengandung arti membangun sifat atau pola perilaku yang didasari atau berkaitan dengan dimensi moral yang positif atau baik, bukan yang negatif atau buruk.

Pendidikan merupakan proses internalisasi budaya ke dalam diri seseorang dan masyarakat sehingga membuat orang dan masyarakat jadi beradab. Pendidikan bukan merupakan sarana transfer ilmu pengetahuan saja, tetapi lebih luas lagi yakni sebagai sarana pembudayaan dan penyaluran nilai (enkulturisasi dan sosialisasi). Anak harus mendapatkan pendidikan yang menyentuh dimensi dasar kemanusiaan. Dimensi kemanusiaan itu mencakup sekurangkurangnya tiga hal paling mendasar, yaitu: (1) afektif yang tercermin pada kualitas keimanan, ketakwaan, akhlak mulia termasuk budi pekerti luhur serta kepribadian unggul, dan kompetensi estetis; (2) kognitif yang tercermin pada kapasitas pikir dan daya intelektualitas untuk menggali dan mengembangkan serta menguasai ilmu pengetahuan dan teknologi; dan (3) psikomotorik yang tercermin pada kemampuan mengembangkan keterampilan teknis, kecakapan praktis, dan kompetensi kinestetis.

Karakter bangsa terbangun atau tidak sangat tergantung kepada bangsa itu sendiri. Bila bangsa tersebut memberikan perhatian yang cukup untuk membangun karakter maka akan terciptalah bangsa yang berkarakter. Bila sekolah dapat memberikan pembangunan karakter kepada para muridnya, maka akan tercipta pula murid yang berkarakter. Demikian pula sebaliknya. Pembentukan karakter menjadi vital dan tidak ada pilihan lagi untuk mewujudkan manusia Indonesia dapat menghadapi tantangan regional dan global. Tantangan regional dan global yang dimaksud adalah bagaimana generasi muda kita tidak sekedar memiliki kemampuan kognitif saja, tetapi aspek afektif dan moralitas juga tersentuh. Untuk itu, pendidikan karakter diperlukan untuk mencapai manusia yang memiliki integritas nilai-nilai moral sehingga anak menjadi hormat sesama, jujur dan peduli dengan lingkungan.

Lickona (1992) menjelaskan beberapa alasan perlunya Pendidikan karakter, di antaranya: (1) Banyaknya generasi muda saling melukai karena lemahnya kesadaran pada nilai-nilai moral, (2) Memberikan nilai-nilai moral pada generasi muda merupakan salah satu fungsi peradaban yang paling utama, (3) Peran sekolah sebagai pendidik karakter menjadi semakin penting ketika banyak anakanak memperoleh sedikit pengajaran moral dari orangtua, masyarakat, atau lembaga keagamaan, (4) masih adanya nilai-nilai moral yang secara universal masih diterima seperti perhatian, kepercayaan, rasa hormat, dan tanggungjawab, (5) Demokrasi memiliki kebutuhan khusus untuk pendidikan moral karena demokrasi 
merupakan peraturan dari, untuk dan oleh masyarakat, (6) Tidak ada sesuatu sebagai pendidikan bebas nilai. Sekolah mengajarkan pendidikan bebas nilai. Sekolah mengajarkan nilai-nilai setiap hari melalui desain ataupun tanpa desain, (7) Komitmen pada pendidikan karakter penting manakala kita mau dan terus menjadi guru yang baik, dan (7) Pendidikan karakter yang efektif membuat sekolah lebih beradab, peduli pada masyarakat, dan mengacu pada performansi akademik yang meningkat.

Upaya untuk mengimplementasikan pendidikan karakter adalah melalui pendekatan holistik, yaitu mengintegrasikan perkembangan karakter ke dalam setiap aspek kehidupan sekolah. Ciri-ciri pendekatan holistik: 1) Segala sesuatu di sekolah diatur berdasarkan perkembangan hubungan antara siswa, guru, dan masyarakat; 2) Sekolah merupakan masyarakat peserta didik yang peduli di mana ada ikatan yang jelas yang menghubungkan siswa, guru, dan sekolah; 3) Pembelajaran emosional dan sosial setara dengan pembelajaran akademik; 4) Kerjasama dan kolaborasi di antara siswa menjadi hal yang lebih utama dibandingkan persaingan; 5) Nilai-nilai seperti keadilan, rasa hormat, dan kejujuran menjadi bagian pembelajaran sehari-hari baik di dalam maupun di luar kelas; 6) Siswasiswa diberikan banyak kesempatan untuk mempraktekkan prilaku moralnya melalui kegiatan-kegiatan seperti pembelajaran memberikan pelayanan; 7) Disiplin dan pengelolaan kelas menjadi fokus dalam memecahkan
Masalah dibandingkan hadiah dan hukuman; 8) Model pembelajaran yang berpusat pada guru harus ditinggalkan dan beralih ke kelas demokrasi di mana guru dan siswa berkumpul untuk membangun kesatuan, norma, dan memecahkan masalah (Elkind \& Sweet, 2005 dalam Qomari, 2010:2).

Sementara itu peran lembaga pendidikan atau sekolah dalam mengimplementasikan pendidikan karakter mencakup (1) mengumpulkan guru, orangtua dan siswa bersama-sama mengidentifikasi dan mendefinisikan unsur-unsur karakter yang mereka ingin tekankan, (2) memberikan pelatihan bagi guru tentang bagaimana mengintegrasikan pendidikan karakter ke dalam kehidupan dan budaya sekolah, (3) menjalin kerjasama dengan orangtua dan masyarakat agar siswa dapat mendengar bahwa prilaku karakter itu penting untuk keberhasilan di sekolah dan di kehidupannya, dan (4) memberikan kesempatan kepada kepala sekolah, guru, orangtua dan masyarakat untuk menjadi model perilaku sosial dan moral.

Mengacu pada konsep pendekatan holistik dan dilanjutkan dengan Upaya yang dilakukan lembaga pendidikan, kita perlu meyakini Bahwa proses pendidikan karakter tersebut harus dilakukan secara berkelanjutan sehingga nilai-nilai moral yang telah tertanam dalam pribadi anak tidak hanya sampai pada tingkatan pendidikantertentu atau hanya muncul di lingkungan keluarga atau masyarakat saja. Selain itu praktik-praktik moral yang dibawa anak tidak terkesan bersifat formali- 
tas, namun benar-benar tertanam dalam jiwa anak.

\section{Kurikulum Tingkat Satuan Pendidikan (KTSP)}

Kurikulum Tingkat Satuan Pendidikan (KTSP) adalah kurikulum operasional yang disusun oleh dan dilaksanakan di masing-masing satuan pendidikan (Pasal 1 Ayat (15) Peraturan Pemerintah Nomor 19 Tahun 2005 Tentang Standar Nasional Pendidikan). KTSP terdiri dari tujuan pendidikan tingkat satuan pendidikan, struktur dan muatan kurikulum tingkat satuan pendidikan, kalender pendidikan, dan silabus.

KTSP dikembangkan sesuai dengan relevansinya oleh setiap kelompok atau satuan pendidikan di bawah koordinasi dan supervisi Dinas Pendidikan atau Kantor Departemen Agama Kabupaten/Kota untuk pendidikan dasar dan provinsi untuk pendidikan menengah. Pengembangan KTSP mengacu pada Standar Isi (SI) dan Standar Kompetensi Lulusan (SKL), dan berpedoman pada panduan penyusunan kurikulum yang disusun oleh Badan Standar Nasional Pendidikan (BSNP), serta memperhatikan pertimbangan komite sekolah/madrasah.

KTSP dikembangkan berdasarkan prinsip-prinsip berpusat pada potensi, perkembangan, kebutuhan, dan kepentingan peserta didik dan lingkungannya, beragam dan terpadu, tanggap terhadap perkembangan ilmu pengetahuan, teknologi dan seni, relevan dengan kebutuhan kehidupan, menyeluruh dan berkesinambungan, belajar sepanjang hayat, seimbang antara kepentingan nasional dan kepentingan daerah.

KTSP disusun dengan memperhatikan peningkatan iman dan takwa serta akhlak mulia, peningkatan potensi, kecerdasan, dan minat sesuai dengan tingkat perkembangan dan kemampuan peserta didik, keragaman potensi dan karakteristik daerah dan lingkungan, tuntutan pembangunan daerah dan nasional, tuntutan dunia kerja, perkembangan ilmu pengetahuan, teknologi, dan seni, agama, dinamika perkembangan global, persatuan nasional dan nilainilai kebangsaan, kondisi sosial budaya masyarakat setempat, kesetaraan jender, karakteristik satuan pendidikan (BSPN, 2006:3-4).

KTSP jenjang pendidikan dasar disusun oleh satuan pendidikan dengan mengacu kepada Standar Isi (SI) dan Standar Kompetensi Lulusan (SKL), serta berpedoman pada panduan yang disusun oleh Badan Standar Nasional Pendidikan (BSNP). Penyusunan KTSP juga harus mengikuti ketentuan lain yang menyangkut kurikulum dalam UU 20/2003 tentang Sistem Pendidikan Nasional dan PP No. 19 Tahun 2005 tentang Standar Nasional Pendidikan (BSPN, 2006:3).

Komponen KTSP jenjang pendidikan dasar terdiri dari komponen tujuan, struktur dan muatan kurikulum, serta kalender pendidikan. Tujuan pendidikan tingkat satuan pendidikan dasar mengacu kepada tujuan umum pendidikan pendidikan, yaitu meletakkan dasar kecerdasan, pengetahuan, kepribadian, akhlak mulia, serta keterampilan untuk 
hidup mandiri dan mengikuti pendidikan lebih lanjut.

Struktur dan muatan muatan KTSP pada jenjang pendidikan dasar meliputi lima kelompok mata pelajaran, yaitu kelompok mata pelajaran agama dan akhlak mulia, kewarganegaraan dan kepribadian, ilmu pengetahuan dan teknologi, estetika, mata pelajaran jasmani, olahraga dan kesehatan (Pasal 6 ayat

(1) Peraturan Pemerintah Nomor 19 Tahun 2005 tentang Standar Nasional Pendidikan).

Muatan KTSP meliputi sejumlah mata pelajaran yang keluasan dan kedalamannya merupakan beban belajar bagi peserta didik pada satuan pendidikan. Di samping itu, materi muatan lokal dan kegiatan pengembangan diri termasuk ke dalam isi kurikulum.

Mata pelajaran beserta alokasi waktu untuk masing-masing tingkat satuan pendidikan berpedoman pada struktur kurikulum yang tercantum dalam SI. Muatan lokal merupakan kegiatan kurikuler untuk mengembangkan kompetensi yang disesuaikan dengan ciri khas dan potensi daerah, termasuk keunggulan daerah, yang materinya tidak sesuai menjadi bagian dari mata pelajaran lain dan atau terlalu banyak sehingga harus menjadi mata pelajaran tersendiri. Substansi muatan lokal ditentukan oleh satuan pendidikan, tidak terbatas pada mata pelajaran keterampilan. Muatan lokal merupakan mata pelajaran, sehingga satuan pendidikan harus mengembangkan Standar Kompetensi dan Kompetensi Dasar untuk setiap jenis muatan lokal yang diselenggarakan. Satuan pendidikan dapat menyelenggarakan satu mata pelajaran muatan lokal setiap semester. Ini berarti bahwa dalam satua tahun satuan pendidikan dapat menyelenggarakan dua mata pelajaran muatan lokal.

Kegiatan pengembangan diri bertujuan memberikan kesempatan kepada peserta didik untuk mengembangkan dan mengekspresikan diri sesuai dengan kebutuhan, bakat, minat, setiap peserta didik sesuai dengan kondisi sekolah. Kegiatan pengembangan diri difasilitasi dan/atau dibimbing oleh konselor, guru, atau tenaga kependidikan yang dapat dilakukan dalam bentuk kegiatan ekstrakurikuler. Kegiatan pengembangan diri dapat dilakukan antara lain melalui kegiatan pelayanan konseling yang berkenaan dengan masalah diri pribadi dan kehidupan sosial, belajar, dan pengembangan karier peserta didik serta kegiatan keparamukaan, kepemimpinan, dan kelompok ilmiah remaja. Pengembangan diri bukan merupakan mata pelajaran. Penilaian kegiatan pengembangan diri dilaku-kan secara kualitatif, tidak kuantitatif seperti pada mata pelajaran.

Ketuntasan belajar setiap indikator yang telah ditetapkan dalam suatu kompetensi dasar berkisar antara $0-100 \%$. Kriteria ideal ketuntasan untuk masing-masing indikator $75 \%$. Satuan pendidikan harus menentukan kriteria ketuntasan minimal dengan mempertimbangkan tingkat kemampuan rata-rata peserta didik serta kemampuan sumber daya pendukung dalam penyelenggaraan pembelajaran. Satuan pendidikan diharapkan meningkatkan kriteria 
ketuntasan belajar secara terus menerus untuk mencapai kriteria ketuntasan ideal.

Kenaikan kelas dilaksanakan pada setiap akhir tahun ajaran. Kriteria kenaikan kelas diatur oleh masing-masing direktorat teknis terkait. Peserta didik dinyatakan lulus dari satuan pendidikan pada pendidikan dasar dan menengah setelah:

a. Menyelesaikan seluruh program pembelajaran;

b. Memperoleh nilai minimal baik pada penilaian akhir untuk seluruh mata pelajaran kelompok mata pelajaran agama dan akhlak mulia, kelompok kewarganegaraan dan kepribadian, kelompok mata pelajaran estetika, dan kelompok mata pelajaran jasmani, olahraga, dan kesehatan;

c. Lulus ujian sekolah/madrasah untuk kelompok mata pelajaran ilmu pengetahuan dan teknologi; dan

d. Lulus ujian nasional (Pasal 72 Ayat (1) Peraturan Pemerintah No. 19 Tahun 2005 tentang Standar Nasional Pendidikan).

Pendidikan kecakapan hidup dapat dimasukkan ke dalam kurikulum yang mencakup kecakapan pribadi, kecakapan sosial, kecakapan akademik dan/atau kecakapan vokasional. Pendidikan kecakapan hidup dapat merupakan bagian integral dari pendidikan semua mata pelajaran dan/atau berupa paket/modul yang direncanakan secara khusus. Pendidikan kecakapan hidup dapat diperoleh peserta didik dari satuan pendidikan yang bersangkutan dan/atau dari satuan pendidikan formal lain dan/atau nonformal.

\section{Pembangunan Karakter Bangsa}

Karakter bangsa merupakan kondisi watak yang merupakan identitas bangsa atau identitas nasional. Identitas nasional dapat diartikan sebagai jatidiri nasional atau kepribadian nasional. Jatidiri nasional suatu bangsa tentu berbeda dengan jatidiri bangsa lain. Ini disebabkan oleh perbedaan latar belakang sejarah, kebudayaan, maupun geografi. Jatidiri nasional bangsa Indonesia terbentuk karena rakyat Indonesia memiliki pengalaman sejarah yang sama. Pengalaman sejarah yang sama itu dapat menumbuhkan kesadaran kebangsaan yang kemudian pada ujungnya melahirkan identitas nasional.

Lahirnya identitas nasional suatu bangsa tidak dapat dilepaskan dari dukungan faktor objektif, yaitu faktor-faktor yang berkaitan dengan geografis-ekologis dan demografis; dan faktor subjektif, yaitu faktorfaktor historis, politik, sosial dan kebudayaan yang dimiliki bangsa itu (Djoko Suryo, 2002:4).

Karakter suatu bangsa akan berkembang berdasarkan pengalaman dalam sejarah bangsa. Suatu bangsa tidak dapat dilepaskan dari pengalaman kehidupan masyarakatnya. Aktivitas masyarakat dalam perkembangan sejarahnya banyak berhubungan dengan pertumbuhan negara bangsa sehingga karakter masyarakat merupakan satu elemen dari suatu karakter bangsa atau kepribadian bangsa.

Karakter suatu bangsa akan terbangun atau tidak sangat tergantung kepada bangsa itu sendiri. 
Apabila bangsa tersebut memberikan perhatian yang cukup untuk membangun karakter, maka akan terciptalah bangsa yang berkarakter. Apabila sekolah dapat memberikan pembangunan karakter kepada para muridnya, maka akan tercipta pula murid yang berkarakter. Demikian pula sebaliknya.

Pembentukan karakter merupakan aspek penting dalam pendidikan. Rumusan pendidikan dalam Pasal 1 Ayat (1) Undang-undang Republik Indonesia Nomor 20 Tahun 2003 tentang Sistem Pendidikan Nasional secara tegas menekankan pentingnya pembentukan karakter, "Pendidikan adalah usaha sadar dan terencana untuk mewujudkan suasana belajar dan proses pembelajaran agar peserta didik secara aktif mengembangkan potensi dirinya untuk memiliki kekuatan spiritual keagamaan, pengendalian diri, kepribadian, kecerdasan, akhlak mulia, serta keterampilan yang diperlukan dirinya, masyarakat, bangsa dan negara."

Pasal 3 Undang-undang Republik Indonesia Nomor 20 tahun 2003 tentang Sistem Pendidikan Nasional secara eksplisit menegaskan tujuan membangun manusia berka-rakter, "Pendidikan nasional berfungsi mengembangkan kemampuan dan membentuk watak serta peradaban bangsa yang bermartabat dalam rangka mencerdaskan kehidupan bangsa, bertujuan untuk berkembangnya potensi peserta didik agar menjadi manusia yang beriman dan bertakwa kepada Tuhan Yang Maha Esa, berakhlak mulia, sehat, berilmu, cakap, kreatif, mandiri, dan menjadi warga negara yang demokratis serta bertanggung jawab."
Pendidikan karakter yang secara sistematis diterapkan dalam pendidikan Dasar dan Menengah hingga pendidikan tinggi merupakan sebuah daya tawar berharga bagi seluruh komunitas. Peserta didik mendapatkan keuntungan dengan memperoleh perilaku dan kebiasaan positif yang mampu meningkatkan rasa percaya dalam diri mereka, membuat hidup mereka lebih bahagia dan lebih produktif. Tugas-tugas pendidik menjadi lebih ringan dan lebih memberikan kepuasan ketika peserta didik memiliki kebiasaan-kebiasaan yang positif. Orang tua bergembira ketika anak-anak mereka belajar untuk menjadi lebih sopan, memiliki rasa horamat dan produktif. Para pengelola sekolah akan menyaksikan berbagai macam perbaikan dalam hal pengenalan nilai-nilai moral.

\section{Metode Penelitian}

Penelitian ini merupakan jenis penelitian desktiptif kualitatif. Metode yang digunakan adalah studi pustaka. Menurut Nazir (1988:111) yang dimaksud dengan penelitian pustaka adalah teknik pengumpulan data dengan mengadakan studi penelaahan terhadap buku-buku, literturliteratur, catatan-catatan, dan laporan-laporan yang ada hubungannya dengan masalah yang dipecahkan.

Studi pustaka adalah penelitian dengan cara mempelajari dan membaca literatur-literatur yang ada hubungannya dengan permasalahan yang menjadi objek penelitian. Data alam penelitian ini diperoleh dari sumber primer dan sekunder. Sumber primer adalah dokumen KTSP dan bahan -bahan pustaka berkualifikasi tinggi terkait dengan kurikulum, 
pendidikan karakter, dan pembangunan bangsa. Data sekundernya adalah bahan-bahan pustaka yang memberikan tambahan penjelasan atas sumber primer.

Bahan-bahan yang terkumpul diolah, diidentifikasi, diklasifikasi, dianalisis dan dideskripsikan berdasarkan rumusan masalah yang pada akhirnya dijadikan bahan pengambilan kesimpulan dan saran. Secara lebih lengkap, langkah-langkah penelitian ini sebagai berikut.

1. Identifikasi muatan pendidikan karakter dalam KTSP.
2. Klasifikasi ranah muatan pendidikan karakter dalam KTSP.

3. Menganalisis dan mendeskripsikan relevansi muatan pendidikan karakter ditinjau dari upaya pambangunan karakter bangsa.

4. Menyimpulkan dan merekomendasikan muatan pendidikan karakter yang relevan dengan tantangan zaman.

Langkah- langkah penelitian tersebut dapat digambarkan sebagai berikut.

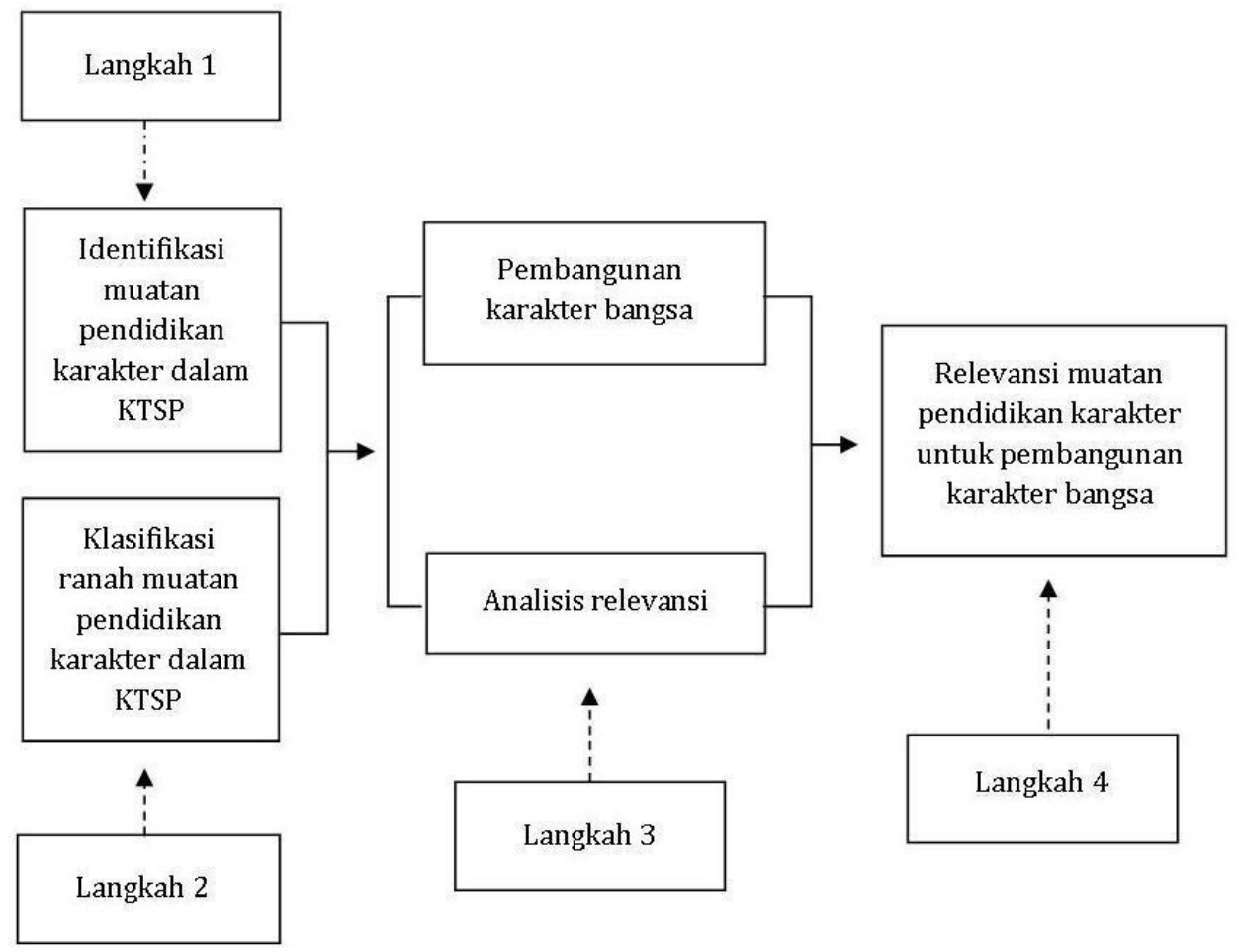

Bagan 1 Langkah-langkah Penelitian 


\section{Hasil Penelitian dan Pembahasan}

\section{A. Hasil Penelitian}

Kedalaman muatan kurikulum pada setiap satuan pendidikan dituangkan dalam kompetensi yang terdiri atas standar kompetensi dan kompetensi dasar pada setiap tingkat dan/atau semester. Standar kompetensi dan kompetensi dasar untuk setiap mata pelajaran pada setiap tingkat dan semester disajikan pada lampiran-lampiran Peraturan Menteri Pendidikan Nasional ini yang terdiri atas: Standar Kompetensi dan Kompetensi Dasar Tingkat SD/MI dan SDLB, Standar Kompetensi dan Kompetensi Dasar Tingkat SMP/MTs dan SMPLB, dan Standar Kompetensi dan Kompetensi Dasar Tingkat SMA/MA/SMALB dan SMK/MAK.

Standar Kompetensi dan Kompetensi Dasar setiap jenjang pendidikan dapat mencerminkan kandungan muatan pendidikan karak-ter. Berikut muatan pendidikan karakter yang terkandung dalam standar kompetensi dan kompetensi dasar mata pelajaran-mata pelajaran pada tingkat SD hingga SMA.

Berdasarkan analisis terhadap rumusan kompentensi dasar dapat diketahui muatan pendidikan karakter yang terkandung dalam matapelajaran matapelajaran KTSP sebagai berikut.

\begin{tabular}{|c|c|c|}
\hline $\begin{array}{l}\text { 1. Jujur } \\
\text { 2. Bertanggung jawab } \\
\text { 3. Hidup bersih } \\
\text { 4. Disiplin } \\
\text { 5. Rajin } \\
\text { 6. Tolong-menolong } \\
\text { 7. Hormat orang tua } \\
\text { 8. Rendah hati } \\
\text { 9. Sopan santun } \\
\text { 10. Setia kawan } \\
\text { 11. Kerja keras } \\
\text { 12. Penyayang } \\
\text { 13. Gigih } \\
\text { 14. Belas kasih } \\
\text { 15. Syukur } \\
\text { 16. Menghargai sesama } \\
\text { 17. Rukun } \\
\text { 18. Bersahabat } \\
\text { 19. Adil } \\
\text { 20. Cinta kasih } \\
\text { 21. Setia } \\
\text { 22. Penyayang } \\
\text { 23. Menjaga kesucian } \\
\text { 24. Kepemimpinan } \\
\text { 25. Berbakti } \\
\text { 26. Bijaksana } \\
\text { 27. Lemah lembut } \\
\text { 28. Pemaaf } \\
\text { 29. Murah hati } \\
\text { 30. Semangat belajar } \\
\text { 31. Sabar }\end{array}$ & $\begin{array}{l}\text { 32. Ulet } \\
\text { 33. Tekun } \\
\text { 34. Teliti } \\
\text { 35. Sederhana } \\
\text { 36. Tawakal } \\
\text { 37. Tertib } \\
\text { 38. Toleran } \\
\text { 39. Tahan menderita } \\
\text { 40. Kritis } \\
\text { 41. Kerja sama } \\
\text { 42. Kebersamaan } \\
\text { 43. Simpati } \\
\text { 44. Empati } \\
\text { 45. Cinta damai } \\
\text { 46. Ikhlas } \\
\text { 47. Iman } \\
\text { 48. Prasangka baik } \\
\text { 49. Taubat } \\
\text { 50. Menghargai karya } \\
\text { orang lain } \\
\text { 51. Ridha } \\
\text { 52. Persatuan } \\
\text { 53. Berani berkompetisi } \\
\text { 54. Etos kerja } \\
\text { 55. Dewasa } \\
\text { 56. Demokratis } \\
\text { 57. Menghargai HAM } \\
\text { 58. Persaudaraan } \\
\text { 59. Pluralis } \\
\text { 60. Inklusif } \\
\text { 61. Mengendalikan diri } \\
\text { 62. Gotong royong }\end{array}$ & $\begin{array}{l}\text { 63. Cinta lingkungan } \\
\text { 64. Musyawarah } \\
\text { 65. Ksatria } \\
\text { 66. Respek diri } \\
\text { 67. Ramah tamah } \\
\text { 68. Taat hukum } \\
\text { 69. Anti korupsi } \\
\text { 70. Menghargai prestasi } \\
\text { 71. Nasionalis } \\
\text { 72. Patriotis } \\
\text { 73. Anti diskriminasi } \\
\text { 74. Santun berbahasa } \\
\text { 75. Kreatif } \\
\text { 76. Hidup sehat } \\
\text { 77. Mandiri } \\
\text { 78. Teratur } \\
\text { 79. Empati } \\
\text { 80. Saleh sosial } \\
\text { 81. Hemat } \\
\text { 82. Waspada } \\
\text { 83. Apresiatif } \\
\text { 84. Ekspresif } \\
\text { 85. Sportif } \\
\text { 86. Percaya diri } \\
\text { 87. Berani } \\
\text { 88. Menghargai lawan } \\
\text { 89. Bersedia berbagi } \\
\text { 90. Tenggang rasa } \\
\text { 91. Terampil } \\
\text { 92. Fleksibel } \\
\text { 93. Estetis } \\
\text { 94. Produktif } \\
\text { 95. Menghargai HAKI }\end{array}$ \\
\hline
\end{tabular}





\section{B. Pembahasan}

Pembangunan karakter bangsa merupakan cita-cita luhur yang harus diwujudkan melalui penyelenggaraan pendidikan yang terarah dan berkelanjutan. Penanaman nilai-nilai akhlak, moral, dan budi pekerti seperti tertuang dalam Undangundang Republik Indonesia Nomor 20 Tahun 2003 tentang Sistem Pendidikan Nasional harus menjadi dasar pijakan utama dalam mendesain, melaksanakan, dan mengevaluasi sistem pendidikan nasional. Pendidikan nasional berfungsi mengembangkan kemampuan dan membentuk watak serta peradaban bangsa yang bermartabat dalam rangka mencerdaskan kehidupan bangsa, bertujuan untuk berkembangnya potensi peserta didik agar menjadi manusia yang beriman dan bertakwa kepada Tuhan Yang Maha Esa, berakhlak mulia, sehat, berilmu, cakap, kreatif, mandiri, dan menjadi warga negara yang demokratis serta bertanggung jawab (pasal 3).

Pembangunan karakter bangsa merupakan upaya kolektif-sistemik untuk mewujudkan kehidupan berbangsa dan bernegara yang sesuai dengan dasar dan ideologi, konstitusi,

haluan negara, serta potensi kolektif dalam konteks kehidupan nasional, regional, dan global yang berkeadaban. Pembangunan karakter bangsa dilakukan secara koheren melalui proses sosialisasi, pendidikan dan pembelajaran, pemberdayaan, pembudayaan, dan kerja sama seluruh komponen bangsa dan negara.

Pembentukan karakter menjadi vital dan tidak ada pilihan lagi untuk menghadapi tantangan regional dan global (Muchlas dalam Sairin, 2001: 211). Tantangan regional dan global yang dimaksud adalah bagaimana generasi muda tidak sekedar memiliki kemampuan kognitif saja, tapi aspek afektif dan moralitas juga tersentuh. Untuk itu, pendidikan karakter diperlukan untuk mencapai manusia yang memiliki integritas nilai-nilai moral sehingga anak menjadi hormat sesama, jujur dan peduli dengan lingkungan.

Pendidikan adalah proses internalisasi budaya ke dalam diri seseorang dan masyarakat sehingga membuat orang dan masyarakat jadi beradab. Pendidikan bukan meruPakan sarana transfer ilmu pengetahuan saja, tetapi lebih luas lagi yakni sebagai sarana pembuDayaan dan penyaluran nilai (enkulturisasi dan sosialisasi). Anak harus mendapatkan pendidikan yang menyentuh dimensi dasar kemanusiaan. Dimensi kemanusiaan itu mencakup sekurang-kurangnya tiga hal paling mendasar, yaitu: (1) afektif yang tercermin pada kualitas keimanan, ketakwaan, akhlak mulia termasuk budi pekerti luhur serta kepribadian unggul, dan kompetensi estetis; (2) kognitif yang tercermin pada kapasitas pikir dan daya intelektualitas untuk menggali dan mengembang-kan serta menguasai ilmu pengetahuan dan teknologi; dan (3) psikomotorik yang tercermin pada kemampuan mengembangkan keterampilan teknis, kecakapan praktis, dan kompetensi kinestetis. KTSP 2006 mengandung 95 nilai karakter. Berdasarkan analisis ranah terhadap rumusan kompetensi 
dasar mata pelajaran-mata pelajaran dalam KTSP 2006, nilai-nilai tersebut telah mencakup tiga ranah (kognitif, afektif, dan psikomotorik) yang cukup seimbang sehingga tinggal bagaimana implementasi kurikulum tersebut di lapangan agar dapat mendukung pembangunan karakter bangsa yang diharapkan.

\section{Simpulan}

Tujuan pembangunan karakter bangsa dicapai melalui muatan kurikulum yang mengandung dimensi kemanusiaan yang mencakup sekurang-kurangnya tiga hal paling mendasar, yaitu: (1) afektif yang tercermin pada kualitas keimanan, ketakwaan, akhlak mulia termasuk budi pekerti luhur serta kepribadian unggul, dan kompetensi estetis; (2) kognitif yang tercermin pada kapasitas pikir dan daya intelektualitas untuk menggali dan mengembangkan serta menguasai ilmu pengetahuan dan teknologi; dan (3) psikomotorik yang tercermin pada kemampuan mengembangkan keterampilan teknis, kecakapan praktis, dan kompetensi kinestetis.

KTSP 2006 mengandung 95 nilai karakter. Nilai-nilai tersebut telah mencakup tiga ranah (kognitif, afektif, dan psikomotorik) yang cukup seimbang sehingga tinggal bagaimana implementasi kurikulum tersebut di lapangan agar dapat mendukung pembangunan karakter bangsa yang diharapkan.

\section{Saran}

Pembentukan karakter menjadi vital dan tidak ada pilihan lagi untuk menghadapi tantangan regional dan global. Tantangan regional dan global yang dimaksud adalah bagaimana generasi muda tidak sekedar memiliki kemampuan kognitif saja, tapi aspek afektif dan moralitas juga tersentuh. Untuk itu, pendidikan karakter diperlukan untuk mencapai manusia yang memiliki integritas nilai-nilai moral sehingga anak menjadi hormat sesama, jujur dan peduli dengan lingkungan. 


\section{Daftar Pustaka}

Azyumardi Azra. 2003. Pendidikan Multikultural: Membangun Kembali Indoneisa Bhineka Tunggal Ika, dalam Tsaqofah, "Menggagas Pendidikan Multikultural", Vol. I, Nomor 2, Tahun 2003.

Badan Standar Nasional Pendidikan. 2006. Panduan Penyusunan Kurikulum Tingkat Satuan Pendidikan Jenjang Pendidikan Dasar dan Menengah. Jakarta: BSPN.

Departemen Pendidikan Nasional. 2006. Materi Sosialisasi Dan Pelatihan Kurikulum Tingkat Satuan Pendidikan (KTSP) Sekolah Dasar. Jakarta: Depdiknas.

Djoko Suryo. 2002. "Pembentukan $\begin{array}{lr}\text { Identitas } & \text { Nasional", } \\ \text { Makalah, Disampaikan pada } & \\ \text { Seminar } & \text { Terbatas } \\ \text { Pengembangan } & \text { Wawasan } \\ \text { tentang Civic } & \text { Education. } \\ \text { Yogyakarta: LP3 UMY, 2002: } & \end{array}$ Elkind, David H. dan Sweet, Freddy. How to Do Character Education. Artikel yang diterbitkan pada bulan September/Oktober 2004. Komaruddin Hidayat. 2006. Dalam A. Ubaedah dan Abdul Rozak (peny.), Demokrasi, Hak Asasi Manusia, dan Masyarakat Madani, Jakarta: CCE UIN Syarif Hidayatullah, 2006.: 54.

Lickona, Thomas, Educating for Character: How Our Schools Can Teach Respect and
Responsibility. New York: Bantam Books, 1992. Qomari Anwar. 2010. "Nilai Agama Sebagai Acuan Membangun Karakter Bangsa," Makalah, Disampaikan dalam

Sarasehan Nasional "Pengembangan Pendidikan Budaya dan Karakter Bangsa" oleh Kopertis Wilayah 3 DKI Jakarta, 12 April 2010. . "Nilai Agama Sebagai Acuan Membangun Karakter Bangsa," Disampaikan dalam Sarasehan Nasional "Pengembangan Pendidikan Budaya dan Karakter Bangsa" oleh Kopertis Wilayah 3 DKI Jakarta, 12 April 2010.

Setiawati Darmojuwono, Peran Stereotipe Dalam Komunikasi Lintas Budaya: Kasus Indonesia-Jerman, dalam http://www.eli.org/main/pdf/ pdf 283.pdf, diakses 18 November 2011.

Suyatno, "Peran Pendidikan Sebagai Modal Utama Membangun Karakter Bangsa", Makalah disampaikan dalam Sarasehan Nasional "Pendidikan Karakter" Yang diselenggarakan Direktorat Jenderal Pendidikan Tinggi dan Kopertis Wilayah III Jakarta, 12 Januari 2010.

Undang-Undang Republik Indonesia Nomor 20 Tahun 2003 tentang Sistem Pendidikan Nasional 

